\title{
Prunus Host Range of Plum pox virus (PPV) in the United States by Aphid and Graft Inoculation
}

\author{
V. D. Damsteegt, USDA, ARS, Foreign Disease-Weed Science Research Unit, Ft. Detrick, MD 21702; R. Scorza, \\ USDA, ARS, Appalachian Fruit Research Station, Kearneysville, WV 25430; A. L. Stone and W. L. Schneider, \\ USDA, ARS, FDWSRU, Ft. Detrick, MD 21702; K. Webb and M. Demuth, USDA, ARS, AFRS, Kearneysville, \\ WV 25430; and F. E. Gildow, Department of Plant Pathology, Penn State University, University Park, PA 16802
}

\begin{abstract}
Damsteegt, V. D., Scorza, R., Stone, A. L., Schneider, W. L., Webb, K., Demuth, M., and Gildow, F. E. 2007. Prunus host range of Plum pox virus (PPV) in the United States by aphid and graft inoculation. Plant Dis. 91:18-23.

Plum pox (Sharka) is a serious virus disease of stone fruits caused by the Plum pox virus (PPV). To determine which species could function as potential hosts and virus reservoirs, we used aphid transmission and bud or chip grafting to evaluate the susceptibility of commercial, ornamental, and wild Prunus species to isolates of PPV found in Pennsylvania, USA. Following inoculation, test trees were observed for symptoms, analyzed by enzyme-linked immunosorbent assay (ELISA) and polymerase chain reaction (PCR), back-assayed to healthy peach, and followed through at least four cold-induced dormancy (CID) cycles over 4 years. Thirty-one of 33 Prunus species and cultivars were systemically infected following aphid transmission. Systemic infection could not be detected in P. cerasus (sour cherry) and $P . \times$ 'Snofozam' (Snow Fountains) despite repeated aphid inoculation attempts. Following grafting of PPV-infected budwood, all 40 species and varieties became infected, although species differed in their susceptibility. Within most species, some individual plants remained PPV negative throughout the study despite repeated inoculations. Infection in some species could be detected only through quantitative reverse transcription (RT)-PCR. Most species displayed clear symptoms, were highly positive by ELISA and RT-PCR, and could be back-inoculated into peach seedlings following CID. Our results indicate that a wide range of native and ornamental Prunus species are susceptible to U.S. isolates of PPV-D.
\end{abstract}

Additional keywords: Myzus persicae, real-time PCR, vernalization

Plum pox (Sharka) is a serious virus disease of Prunus species and is considered the most important viral disease of stone fruit trees in Europe and the Mediterranean region (32). Symptoms of plum pox in plum were observed as early as 1915 to 1917 in Bulgaria, although its viral nature was not described until 1932 (1) as a pox of plum (Sharka). The first report of plum pox in apricot was in 1934 in Bulgaria (6) and in peaches in Hungary in the early 1960s (25). The disease spread slowly across Europe, reaching the Iberian Peninsula in 1984. It was identified in Egypt in 1986 (9), in Chile (1992) (15), the United States (1999) (21), Canada (2000) (36),

Corresponding author: V. D. Damsteegt

E-mail: vern.damsteegt@ars.usda.gov

Accepted for publication 16 August 2006.

DOI: 10.1094/PD-91-0018

This article is in the public domain and not copyrightable. It may be freely reprinted with customary crediting of the source. The American Phytopathological Society, 2007. and China (2005) (24). The causal agent, Plum pox virus (PPV: genus Potyvirus; family Potyviridae) (4), is the only potyvirus known to infect Prunus species and is transmitted nonpersistently by many aphid species $(10,20)$. There are four wellrecognized strains of PPV consisting of PPV-M (Marcus), PPV-D (Dideron), PPVEA (El Amar), and PPV-C (sour and sweet cherry) (5,32). A putative new strain has been identified in Canada $(17,36)$, and a natural population of a recombinant PPV strain has been reported in Slovakia $(11,12)$.

There are numerous reports of natural and experimentally generated host ranges for PPV $(8,14,18,19,26,28-31,34,37)$. Many of these reports preceded the determination of specific PPV strains, and isolates were characterized by reactions on various indicator plants such as Chenopodium foetidum $(27,35)$. For many years, PPV was believed to be restricted to the Prunus genus (26), although it had been reported to infect Sorbus (34). Privet (Ligustrum vulgare) and Euonymus (Euonymus europea) (29) were found as natural hosts of PPV in Poland in 2001, and walnut (Juglans regia) was reported as a natural host by Baumgartnerova in 1997 (3), although this has not been confirmed. Nemeth (26) lists eight Prunus species as natural hosts and an additional 33 Prunus species and hybrids as susceptible to infection when experimentally inoculated with European strains of PPV. Approximately 15 naturally infected herbaceous ornamental and weedy hosts have been identified in orchards in association with Prunus species, and an additional 106 herbaceous species have been experimentally infected (26). Many questions remain concerning host range, as most early studies did not report on the PPV source, exact mode of transmission, or host cultivars studied. We now know that both woody and herbaceous host susceptibility are dependent on the strain of PPV used in studies (26). After PPV (D strain) was identified in Pennsylvania (USA), a quarantine and eradication program was immediately instituted by the Pennsylvania Department of Agriculture and the United States Department of Agriculture, Animal and Plant Health Inspection Service (APHIS). As part of this program, studies were initiated to determine the host range of the Pennsylvania isolates of PPV among woody and herbaceous species identified in the affected area that might serve as PPV reservoirs for aphid transmission or as sources for unintended graft transmissions. Since natural spread of PPV in an orchard could be by one to several aphid species (20), we initially collected and identified migratory aphid species from peach orchards in Pennsylvania (38) and tested the most common of these species as potential vectors of the Pennsylvania PPV isolates. Upon determination of the most efficacious aphid vectors (10), we initiated a host range study based on aphid transmission and graft transmission to identify the potential woody hosts of the PPV isolates found in Pennsylvania.

One objective of this study was to identify Prunus species capable of supporting long-term systemic PPV infections through repeated cold-induced dormancy (CID) cycles, as occurs annually in nature. It is hypothesized that these species could be 
effective in maintaining a long-term PPV reservoir that could endanger any attempted eradication program, especially if infected plants remain asymptomatic at least part of the year. A second objective was to compare susceptibility of Prunus species to PPV infection by either aphid or graft transmission and to compare these results to previous reports.

\section{MATERIALS AND METHODS}

Host species, insect vectors, virus isolates. A total of 49 different Prunus genotypes, including 41 designated species, some with multiple varieties or cultivars, were tested for their ability to support PPV infection and over-wintering survival. The Prunus species utilized in this study were obtained as seed or seedlings from commercial nurseries, seed suppliers, and the National Arboretum, Washington, D.C. (kindly provided by M. Pooler). Because Prunus species are open-pollinated, there can be considerable variability among seedlings, and unless cultivar nomenclature was available for commercial types, designation was only to species. Seeds were stratified for 3 months in moist sphagnum moss under dark conditions at $4^{\circ} \mathrm{C}$. Upon germination, seedlings were planted into a mixture of soil, vermiculite, perlite, and MetroMix 510 (Scotts-Sierra Horticultural Products Co., Marysville, $\mathrm{OH})$ on a greenhouse bench at $25^{\circ} \mathrm{C}$. Prior to PPV inoculation, seedlings were tested by enzyme-linked immunosorbent assay (ELISA) (7) to verify the test plants were free of Prunus necrotic ringspot virus, Prune dwarf virus, and Tomato ringspot virus. For aphid transmission, Prunus seedlings were inoculated at the 10- to 12-leaf stage. For grafting, tree seedlings were grown to a stem caliper of 6 to $7 \mathrm{~mm}$. Some species were purchased as bare-rooted seedlings with stem calipers of 7 to $8 \mathrm{~mm}$.

Green peach aphids (Myzus persicae Sulzer) were reared on caged turnips (Brassica rapa L.) in a virus-free insectary at the Pennsylvania State University (10). Colonies were harvested when aphid populations reached their peak growth stage, approximately 3 weeks after initiation, and transported to the BL3-P biocontainment facility at Ft. Detrick (23).

Inoculum for aphid transmissions consisted of highly symptomatic peach leaves (cvs. Lovell or GF 305) previously inoculated with PPV-PENN 3 or PENN 4 isolates. PPV-PENN 3 was isolated from a naturally infected 'Flame Prince' peach tree found in a commercial orchard in Cumberland County, PA and grafted onto 'GF 305'. PPV-PENN 4 was isolated from peach fruit growing on a naturally infected tree in a commercial orchard and transferred to 'Lovell' peach by aphids. Both PPV isolates were readily transmitted by the green peach aphid (10).

Aphid inoculations. Thirty-three different Prunus species and genotypes were tested by aphid inoculations (Table 1). To begin an aphid inoculation test, healthy aphid adults and nymphs were shaken from colony plant leaves into plastic dishes for a 30- to 60-min starvation period. Highly symptomatic leaves from infected peach seedlings were placed into the aphid containers, and the aphids were allowed to settle on the leaves and begin probing during a 30-min acquisition access period. To begin the inoculation access period (IAP), a leaf bearing 50 to 100 probing aphids was placed on each test seedling, and the seedling was covered with a tube cage for a 48-h IAP during which the aphids were allowed free movement from the inoculum leaves to the seedlings. In an alternative inoculation protocol, approximately 500 aphids were shaken directly onto intact PPV-infected seedlings, allowed to settle and begin probing. The aphid-infested, PPV-infected seedlings then were placed with the healthy test seedlings into Lucite box cages $(39 \times 51 \times 37 \mathrm{~cm})$, and aphids were allowed to freely roam from infected source seedlings to healthy test seedlings for a 4- to 7-day IAP. Experiments conducted during the study indicated that the type of aphid inoculation did not affect the outcome and there was no difference in percent transmission among inoculation methods in controlled experiments (data not shown). In all inoculation experiments, there were at least 50 aphids per test seedling at the end of the IAP. With each inoculation experiment, one to several (dependent on number available) test seedlings were infested with virus-free aphids as negative controls. Susceptible 'Lovell' peach seedlings were included with each inoculation as positive inoculum controls.

The IAP was terminated by spraying the seedlings with an insecticide. Test seedlings were placed on greenhouse benches at 20 to $25^{\circ} \mathrm{C}$ with natural daylight supplemented by 400 watt sodium lamps for a 16-h day length. Seedlings were fertilized biweekly with Osmocote (Scott-Sierra Horticultural Products).

Sequential redundant assays were done to verify the PPV infection status of test seedlings. Symptoms were recorded as they appeared up to 45 days postinoculation. All seedlings, regardless of symptoms, were tested by ELISA between 21 and 45 days (Durviz kit) according to manufacturer's instructions (Agdia Inc., Elkhart, IN). ELISA samples consisted of $1 \mathrm{~g}$ of leaf tissue taken from the newest fully expanded leaves; never from leaves fed on by aphids. ELISA samples were run in paired wells and read at 1 and $24 \mathrm{~h}$ at $405 \mathrm{~nm}$ on a Molecular Devices SpectraMax 340PC (Molecular Devices, Sunnyvale, $\mathrm{CA}$ ). Positive threshold values were set at $4 \times$ the standard deviation of healthy controls. Regrowth following CID treatments was sampled in the same manner. Seedlings remaining asymptomatic and negative by ELISA were sampled for po- lymerase chain reaction (PCR) by taking 10 leaf punches from one or two fully expanded leaves, which were quick-frozen in liquid nitrogen $\left(\mathrm{LN}_{2}\right)$, pulverized, and RNA extracted using RNAqueous extraction kits according to manufacturer's instructions (Ambion, Inc., Austin, TX). Subsequent reverse transcription (RT)PCR assays were performed by using previously described protocols (33) on a conventional thermal cycler without the use of fluorescent probe. Seedlings testing positive for PPV infection by either ELISA or PCR became the source plants for backinoculations to young 'Lovell' peach seedlings using the green peach aphid. The resulting aphid-inoculated peach seedling indicator plants were further tested by ELISA to verify infection.

Following the ELISA, PCR assays, and back-inoculations, leaves were stripped from test seedlings, after stems had become woody, and the seedlings were incubated at $4{ }^{\circ} \mathrm{C}$ for an 8 -week CID treatment. Upon removal from the cold treatment, test plants were allowed to grow at 20 to $25^{\circ} \mathrm{C}$. Seedlings were observed for symptoms for 45 days and analyzed by ELISA. Following the CID treatment, plants were grown for several months in the greenhouse and then subjected again to CID. This CID cycle was repeated at least four times over 4 years.

Grafting inoculations. Forty Prunus species and genotypes were tested by graft inoculation (Table 1). Generally, six to eight plants per species/genotype were inoculated by bud grafts and two plants were nongrafted controls. Trees were inoculated by budding two PPV-infected vegetative buds, one each cut from nodes of $P$. tomentosa (Nanking Cherry) and $P$. persica 'Lovell' or 'GF 305' that originally had been bud-grafted with PPV-PENN 2 or PENN 3, respectively (PENN 2 was isolated from a naturally infected plum tree in Adams County, PA and grafted onto $P$. tomentosa). Leaf samples from shoots used for inoculation were tested by ELISA as above to verify PPV infection of the budwood sources. Two Prunus species were used as inoculum sources to reduce the possibility of interspecific graft incompatibility which could inhibit virus transfer. In cases where scion shoots grew out from the inoculum buds, both test plants and inoculum shoots were tested for PPV infection. Plants that were PPV negative in a particular test were reinoculated by grafting at least once and in some cases up to four times.

One to two months following each inoculation event, leaves were removed and the plants were placed in the dark at $4^{\circ} \mathrm{C}$ for an 8- to 16-week CID treatment. Throughout the study, graft-inoculated plants were exposed to CID five times at various intervals. Following CID, plants were allowed to grow for 1 to 2 months, observed for symptoms, sampled, and 
analyzed by ELISA and RT-PCR during the active growth phase.

Real-time RT-PCR. Total RNA was extracted from grafted test plants using the Purescript kit (Gentra Systems Inc., Minneapolis, MN) modified as previously described
(16). Quantitative real-time RT-PCR was performed on extracted RNA as previously described (16), modified to use primers and probe designed to detect the PPV NIb gene (33). RNA quality was verified by amplification of chlorophyll $\mathrm{a} / \mathrm{b}$ binding mRNA (2).

\section{RESULTS}

A total of 49 Prunus species and/or genotypes were inoculated with the PENN 2, PENN 3, or PENN 4 isolates of PPV using grafting or aphid transmission (Table 1). Ten of the 49 species and genotypes

Table 1. Prunus susceptibility to Pennsylvania isolates of Plum pox virus (PPV) as assessed by aphid and graft inoculation

\begin{tabular}{|c|c|c|c|c|c|c|c|c|}
\hline \multirow[b]{2}{*}{ Species $^{\mathbf{a}}$} & \multirow[b]{2}{*}{ Common name ${ }^{b}$} & \multicolumn{5}{|c|}{ Aphid } & \multirow[b]{2}{*}{$\begin{array}{l}\text { Graft } \\
\text { PCR }^{h}\end{array}$} & \multirow[b]{2}{*}{$\begin{array}{r}\text { Priol } \\
\text { cit. }{ }^{i}\end{array}$} \\
\hline & & $\begin{array}{c}\text { Visual } \\
\text { Symp.c }\end{array}$ & ELISA $^{d}$ & $\mathbf{P C R}^{\mathrm{e}}$ & $\begin{array}{l}\text { Back- } \\
\text { assay }^{\text {f }}\end{array}$ & $\begin{array}{l}\text { Post- } \\
\text { CIDg }\end{array}$ & & \\
\hline \multicolumn{9}{|l|}{ Graft and aphid inoculated } \\
\hline Prunus americana & American plum & $8 / 23$ & $11 / 23$ & + & + & + & $1 / 6$ & $\mathrm{~S}$ \\
\hline P. andersonii & Desert peach & $0 / 9$ & $1 / 9$ & + & NA & NA & $3 / 5$ & \\
\hline P. angustifolia & Chickasaw plum & $14 / 21$ & $9 / 21$ & + & + & + & $3 / 6$ & \\
\hline P. armeniaca & Apricot & $15 / 31$ & $11 / 31$ & + & + & + & $3 / 6$ & $\mathrm{~S}$ \\
\hline (P. avium 'Mazzard')-OPj & Sweet cherry & $10 / 54$ & $11 / 54$ & + & + & + & $3 / 6$ & \\
\hline P. cistena & Purple leaf sand cherry & $0 / 65$ & $3 / 65$ & + & - & - & $4 / 14$ & \\
\hline P. davidiana & David's peach & $0 / 13$ & $5 / 13$ & + & + & + & $3 / 5$ & $\mathrm{~S}$ \\
\hline P. domestica 'Brompton' & Garden plum & $2 / 2$ & $2 / 2$ & + & + & + & $5 / 5$ & $\mathrm{~S}$ \\
\hline P. emarginata & Bitter cherry & $4 / 32$ & $7 / 32$ & + & + & + & $4 / 6$ & I \\
\hline P. incam 'Okame' & Flowering cherry & $0 / 13$ & $2 / 13$ & - & NA & - & $2 / 6$ & \\
\hline P. mahaleb & Mahaleb cherry & $6 / 74$ & $19 / 74$ & + & + & + & $3 / 6$ & $\mathrm{~S}$ \\
\hline P. maritima & Beach plum & $3 / 3$ & $3 / 3$ & + & + & + & $1 / 4$ & $\mathrm{~S}$ \\
\hline P. nigra & Canadian plum & $0 / 3$ & $1 / 3$ & + & + & + & $3 / 5$ & $\mathrm{~S}$ \\
\hline P.padus & European bird cherry & $4 / 45$ & $14 / 45$ & + & + & + & $4 / 5$ & I \\
\hline P. pensylvanica & Pin cherry & $2 / 44$ & $13 / 44$ & + & + & + & $5 / 13$ & I \\
\hline P. pumila var. besseyi & Western sand cherry & $6 / 39$ & $14 / 39$ & + & + & + & $6 / 8$ & $\mathrm{~S}$ \\
\hline P. pumila var. depressa & Eastern sand cherry & $0 / 35$ & $22 / 35$ & + & + & + & $3 / 8$ & $\mathrm{~S}^{\mathrm{k}}$ \\
\hline$P$. serotina & Black cherry & $11 / 78$ & $35 / 78$ & + & + & + & $1 / 6$ & \\
\hline P. serrulata 'Kwansan' & Kwansan cherry & $0 / 13$ & $0 / 13$ & + & NA & + & $1 / 6$ & \\
\hline P. $\times$ 'Snofozam' (Snow Fountains) & Snow Fountain cherry & $0 / 17$ & $0 / 17$ & - & NA & - & $3 / 6$ & \\
\hline P. triloba & Flowering almond & $3 / 5$ & $3 / 5$ & + & + & + & $3 / 8$ & $\mathrm{~S}$ \\
\hline P. virginiana & Chokecherry & $10 / 35$ & $11 / 35$ & + & + & + & $2 / 7$ & \\
\hline P. virginiana var. demissa & Western chokecherry & $3 / 21$ & $4 / 21$ & + & + & + & $4 / 4$ & \\
\hline \multicolumn{9}{|l|}{ Aphid inoculated } \\
\hline P. cerasifera & Cherry plum & $12 / 14$ & $8 / 14$ & + & + & + & NA & $\mathrm{S}$ \\
\hline$P$. cerasus & Sour (tart) cherry & $0 / 19$ & $0 / 19$ & - & - & - & NA & \\
\hline P. domestica subsp. insititia & Bullace plum & $1 / 2$ & $1 / 2$ & NA & + & + & NA & $\mathrm{S}$ \\
\hline P. dulcis 'Butte' and 'Mission' & Almond & $3 / 30$ & $17 / 30$ & + & + & + & NA & \\
\hline P. humilis & Humble bush cherry & $10 / 18$ & $12 / 18$ & + & + & + & NA & \\
\hline P. laurocerasus 'Schipkaensis' & 'Schipkaensis' cherry laurel & $0 / 29$ & $3 / 29$ & + & NA & - & NA & $\mathrm{I}$ \\
\hline P. mume & Japanese apricot & $12 / 12$ & $12 / 12$ & + & + & + & NA & $\mathrm{S}$ \\
\hline P. salicina & Japanese plum & $3 / 21$ & $5 / 21$ & + & + & + & NA & $\mathrm{S}$ \\
\hline P. serrulata & Japanese flowering cherry & $9 / 15$ & $9 / 15$ & + & + & + & NA & \\
\hline$P$. spinosa & Blackthorn, sloe & $1 / 1$ & $1 / 1$ & NA & + & NA & NA & $\mathrm{S}$ \\
\hline \multicolumn{9}{|l|}{ Graft inoculated } \\
\hline P. blireana & & NA & NA & NA & NA & NA & $5 / 5$ & $\mathrm{~S}$ \\
\hline P. cerasifera 'Myrobalana' & Myrobalan plum & NA & NA & NA & NA & NA & $6 / 8$ & $\mathrm{~S}$ \\
\hline P. cerasifera 'Thundercloud' & Myrobalan plum & NA & NA & NA & NA & NA & $2 / 7$ & \\
\hline P. fruticosa & European dwarf cherry & NA & NA & NA & NA & NA & $4 / 10$ & I \\
\hline P. glandulosa 'Rosea Plena' & Dwarf flowering almond & NA & NA & NA & NA & NA & $3 / 6$ & $\mathrm{~S}$ \\
\hline P. hortulana & Wild goose plum & NA & NA & NA & NA & NA & $2 / 3$ & $\mathrm{~S}$ \\
\hline P. ilicifolia & Holly leaf cherry & NA & NA & NA & NA & NA & $4 / 6$ & \\
\hline (P. incam 'Okame') - OP 'Dream Catcher' & Flowering Cherry & NA & NA & NA & NA & NA & $2 / 6$ & \\
\hline P. incisa & & NA & NA & NA & NA & NA & $2 / 6$ & \\
\hline P. laurocerasus 'Otto Luyken' & 'Otto Luyken' cherry laurel & NA & NA & NA & NA & NA & $4 / 7$ & $\mathrm{I}$ \\
\hline P. lyonii & Catalina Isl. cherry & NA & NA & NA & NA & NA & $6 / 6$ & \\
\hline P. maackii & Manchurian cherry & NA & NA & NA & NA & NA & $3 / 7$ & \\
\hline P. mexicana & Mexican plum & NA & NA & NA & NA & NA & $3 / 4$ & \\
\hline P. sargentii & Sargent's cherry & NA & NA & NA & NA & NA & $2 / 6$ & \\
\hline P. subhirtella 'Pendula' & Equinox cherry & NA & NA & NA & NA & NA & $3 / 7$ & \\
\hline P. tenella & Dwarf Russian almond & NA & NA & NA & NA & NA & $3 / 7$ & \\
\hline P. yedoensis & Yoshino flowering cherry & NA & NA & NA & NA & NA & $5 / 12$ & \\
\hline
\end{tabular}

a Nomenclature taken from Scientific and Common Names of 7000 Vascular Plants in the United States, American Phytopathological Society, 1995.

${ }^{\mathrm{b}}$ Common names taken from Hortus Third, Macmillan Publishing Co., New York, 1976.

c Visual symptoms: number of plants with symptoms/total number of plants.

${ }^{\mathrm{d}}$ ELISA (enzyme-linked immunosorbent assay): number of plants with $405 \mathrm{~nm}$ absorbance levels $4 \times$ higher than negative controls/total plants.

e Polymerase chain reaction (PCR): NA $=$ not attempted, $+=$ positive,$-=$ negative.

f Back-assay positive transmission to peach using Myzus persicae.

g Post-CID: Post cold-induced dormancy (symptomatic and/or ELISA positive).

h Number of positive plants by real-time PCR/total number of plants.

i Previously reported by Nemeth, 1986, as susceptible (S) or immune (I).

$\mathrm{j}$ Open pollinated.

${ }^{k}$ Possibly reported as Prunus pumila. 
were inoculated using only aphids, 17 were inoculated using only grafting, and 23 were inoculated using both methods. Except for $P$. cerasifera $\mathrm{cv}$. Thundercloud, $P$. incam cv. Okame, $P$. serrulata cv. Kwansan, $P$. laurocerasus cvs. Otto
Luyken and Schipkaensis, and $P . \times$ 'Snofozam', all test plants represented populations derived from seed.

Thirty-one of 33 species inoculated by aphids tested positive for PPV (Table 1). Only $P$. cerasus and $P . \times$ 'Snofozam'
(Snow Fountains) remained PPV negative following aphid inoculation when tested by RT-PCR and ELISA. There were large differences among species in terms of percent infection, ranging from $5 \%$ for $P$. cistena to $100 \%$ for $P$. mume. PPV was
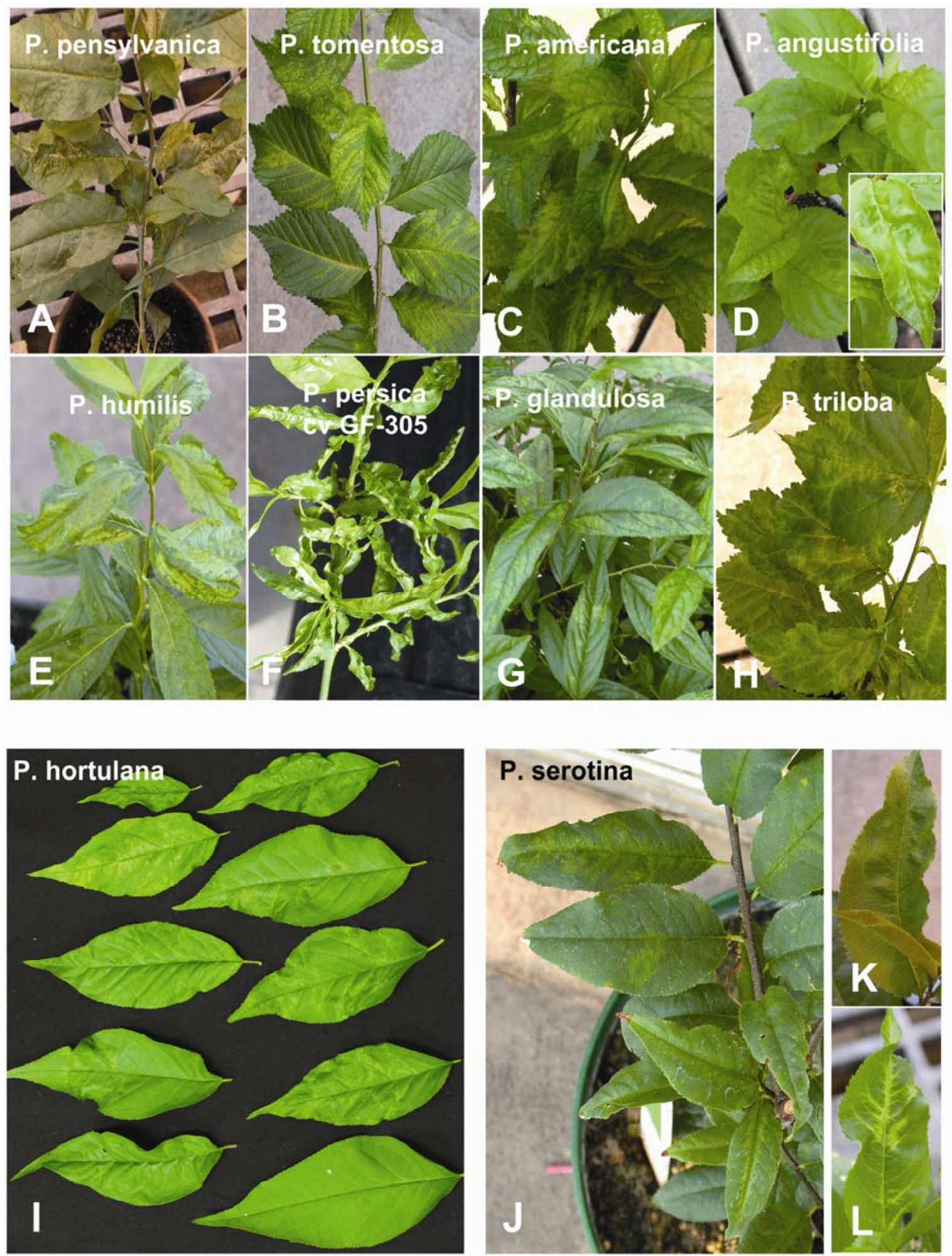

Fig. 1. Prunus species expressing symptoms of Plum pox virus PPV-PENN 3 or PENN 4 following inoculation with Myzus persicae: A, sharp chlorotic and necrotic vein patterns on only three to four leaves; $\mathbf{B}, \mathbf{C}$, and $\mathbf{H}$, blotchy, vein-associated chlorotic patterns with some leaf twisting on midbranch leaves; D, mild, diffuse chlorotic mosaic, slight leaf twisting; E, strong chlorotic mosaic on most leaves; $\mathbf{F}$, chlorotic veins, leaf-twisting, irregular margins, and stunted growth on GF 305 peach; G, diffuse chlorotic mosaic on most leaves; I, diffuse, vein-associated chlorotic patterns, some leaf-twisting, and chlorotic rings; and $\mathbf{J}, \mathbf{K}$, and $\mathbf{L}$, range of chlorotic ring and oakleaf patterns, mosaic, and leaf deformation on a few leaves per branch of black cherry. Complete descriptions in text. 
successfully back-inoculated to peach from most positive species except $P$. cistena and $P$. laurocerasus cv. Schipkaensis. In addition, PPV persisted through CID in all species except for $P$. cistena and P. laurocerasus cv. Schipkaensis, indicating little systemic movement and/or persistency. Back-inoculations were not attempted with $P$. andersonii, $P$. incam cv. Okame, and $P$. serrulata cv. Kwansan.

All 40 species and varieties that were graft-inoculated yielded at least one infected plant (Table 1). An average of $49 \%$ of all graft-inoculated plants were infected, ranging from 17 to $100 \%$ of the plants of a given species or genotype. There was a wide variation in detectable levels of PPV by real-time RT-PCR among the grafted hosts, with several species showing mild symptoms having low virus titer based on high detection threshold cycle values $\left(\mathrm{C}_{\mathrm{T}}\right)$ (28-38), others with strong symptoms having low $C_{T}$ values. Relative $C_{T}$ values obtained with the susceptible PPV source species were $15-21$. Relative $C_{T}$ values were affected by seasonal parameters, age of infection, etc., with low $\mathrm{C}_{\mathrm{T}}$ values at one time point and very high $\mathrm{C}_{\mathrm{T}}$ values at other time points (data not shown).

Symptoms were observed in 23 of 33 aphid-inoculated species within 4 weeks postinoculation (Table 1). Symptoms varied, with each species ranging from strong, persistent, chlorotic patterns and leaf twisting on all new growth, i.e., $P$. cerasifera, $P$. humilis, $P$. mume, $P$. salicina, and $P$. spinosa, to a transient, mild mosaic on a few leaves and branches, i.e., $P$. americana, $P$. angustifolia, $P$. pensylvanica, $P$. serotina, $P$. triloba, and $P$. virginiana (Fig. 1). In most of the mildly symptomatic plants, symptoms disappeared 2 to 3 months postemergence, and trees were asymptomatic when placed into CID. Following 8 weeks at $4^{\circ} \mathrm{C}$, the plants were allowed to regrow and were examined for symptoms. Surviving plants that were symptomatic pre-CID again became symptomatic post-CID. Of the 10 asymptomatic species by aphid transmission (Table 1), all but two, $P$. cerasus and $P . \times$ 'Snofozam', had plants that were positive by ELISA. Aphid-inoculated $P$. cerasus and $P$. $\times$ 'Snofozam' were negative in all assays. In all aphid transmission experiments, the susceptible control ( $P$. persica 'Lovell') seedlings were strongly symptomatic, indicating the inoculating aphids were viruliferous.

Symptoms produced on species inoculated by aphid transmission and by grafting were similar. Eastern ( $P$. virginiana) and western $(P$. virginiana var. demissa) chokecherry were systemically infected following aphid transmission and grafting. Symptoms were very mild and transient, although the infection persisted through CID and could be back-inoculated into peach with aphids. P. glandulosa (Fig. 1) and $P$. mexicana (not shown), inoculated by grafting, exhibited chlorotic leaf pat- terns in response to PPV infection. Aphids allowed to probe on the $P$. glandulosa were able to transfer PPV back to peach.

In all inoculation experiments, noninoculated controls of each species tested remained free of symptoms and negative in all assays. Positive peach seedlings with strong mosaic symptoms had average ELISA absorbance values of 1.5 to 2.5 after $1 \mathrm{~h}$. All species showing similar strong mosaic symptoms (Fig. 1) had ELISA absorbance values comparable to peach. Positive asymptomatic species had varying absorbance values ranging from 0.1 to 0.5 , depending on the species (negative controls were 0.0 ) after $1 \mathrm{~h}$ (data not shown).

\section{DISCUSSION}

Our results demonstrate that a wide range of Prunus species, wild and ornamental, many native to the United States, are susceptible to Pennsylvania isolates of PPV and can maintain a PPV titer over a long time period. Some species appear to develop a high virus titer and show clear symptoms, while in others the virus is detectable only by means of highly sensitive analyses, such as quantitative real-time RT-PCR. A few species in the sampled germ plasm appear to be highly resistant to PPV based on the percentage of infection and RT-PCR, but there was no evidence of immunity in any genotype. This is in contrast to previously reported host ranges (26), in which a number of species were reported not to support PPV infection (Table 1). It is important to note that there is considerable biological variation among PPV-D isolates, and the inoculum strains used here represent three isolates from Pennsylvania. In addition, there is considerable variation among cultivars, and individuals of seedling populations of Prunus species are genetically variable.

There was some variability between grafting results and aphid transmissions, particularly in terms of the percent infected, although in most species tested by both methods the results were comparable (Table 1). The variability that was evident may be associated with intrinsic differences between graft and aphid inoculation techniques, differences in plant age/size (grafted plants were older and larger than aphid-inoculated seedlings), variation in aphid probing behavior on different plant species, variation in cultural conditions, and timing of inoculation and sampling. Rarely were $100 \%$ of all test plants of any species infected by either inoculation method, and repeated aphid inoculations of negative plants of a given species or repeated grafting did not greatly increase the percentage of infection in most species. This may be indicative of the variability in open-pollinated seed and may indicate a level of natural resistance. We do not know how well the seedling populations of species represent the diversity of the species with respect to resistance to PPV. For example, apricots ( $P$. armeniaca) are generally regarded as highly susceptible to PPV, yet there are several cultivars that have been shown to be highly resistant (22).

The PPV symptoms observed in this study varied from mild to strong and often were transient. For example, sweet cherry (Mazzard) ( $P$. avium) demonstrated mild symptoms on young leaves following grafting and aphid inoculation. Symptoms disappeared within 30 days, yet asymptomatic plants remained positive for PPV infection by ELISA, PCR, and backinoculation to peach, before and following CID treatment. However, no symptoms appeared on $P$. avium post-CID, although plants remained systemically infected. Black cherry $(P$. serotina) plants, on the other hand, produced mild chlorotic symptoms on some leaves of a few branches (Fig. 1), which were transient in nature, followed by the production of new asymptomatic leaves. In contrast to sweet cherry ( $P$. avium), however, infected $P$. serotina continued to show mild transient symptoms following CID. In addition, in $10 \%$ of the $P$. serotina trees, the observed symptoms post-CID were stronger than symptoms observed pre-CID. Black cherry plants have been carried through four CID treatments over 3 years, with transient symptoms visible on a few leaves each post-CID. These leaves always tested positive by ELISA and by back-inoculation to peach after each CID. Asymptomatic leaves always were negative by ELISA and/or PCR. This suggests that $P$. serotina could serve as a reservoir of PPV in nature that could be overlooked in surveys.

Initial bud growth on $P$. americana postCID produced vivid mosaic-patterned leaves. As the branch terminal buds continued to grow, new leaves were asymptomatic. Samples from symptomatic leaves were highly positive by ELISA, and samples from the asymptomatic leaves of each branch were negative by ELISA. This would indicate that in nature only the early leaves would be a source of virus and, unless surveyed at the correct time, the tree would test as negative.

Graft-inoculated and noninoculated plants were assayed by real-time RT-PCR as a measure of virus titer and indication of possible resistance. Some graftinoculations were repeated several times in an attempt to obtain some infected plants. As with aphid inoculations, some species were asymptomatic or very mildly symptomatic and others exhibited strong chlorotic symptoms. Virus titer, as indicated by low or high $\mathrm{C}_{\mathrm{T}}$ values, was variable among species and within species, dependent on environmental and biological factors.

In some cases, graft compatibility between the species used as inoculum $(P$. persica and $P$. tomentosa) and $P$. laurocerasus cv. Otto Luyken, $P$. lyonii, and $P$. 
virginiana var. demissa could have affected virus transmission. Although $P$. yedoensis and $P$. fruticosa were observed to have had poor graft compatibility with the inoculum sources, $\mathrm{C}_{\mathrm{T}}$ values as low as 18.47 and 21.50 were obtained, respectively, indicating a high titer in those species. In contrast, $P$. andersonii had excellent graft compatibility with the inoculum sources. However, RNA extracted from leaves of the peach scion shoots that grew out from $P$. andersonii gave average $\mathrm{C}_{\mathrm{T}}$ values of 15.93 and 21.01 on two assay dates, while the $P$. andersonii stocks gave average $\mathrm{C}_{\mathrm{T}}$ values of 34.54 and 34.58, respectively, suggesting a high level of resistance not due to graft incompatibility.

Several species tested positive at one time point in the multiple CID cycles and negative at different time points. This phenomenon has been observed in plum trees (13) and in surveyed peaches in Pennsylvania (Ruth Welliver, Pennsylvania Department of Agriculture, personal communication), further illustrating the difficulties facing PPV eradication programs.

Under the conditions of this study, we have shown that PPV isolates from Pennsylvania have a broad potential host range among woody Prunus species as evidenced by graft and aphid inoculations. Virus titers varied widely among and within openpollinated species. The basis of this variation likely has genetic, physiological, and environmental components. Many species appear to be potential virus reservoirs. The virus may be transferred from these species, even in the absence of symptoms, to other susceptible hosts. While it is tempting to classify a species as PPV resistant or susceptible, and while this may be useful for regulatory issues, the potential for resistant genotypes within a "susceptible" species and susceptible genotypes within a "resistant" species should not be discounted. These findings suggest that resistance to PPV in Prunus is a question of degree and not an absolute.

It will be important to continue the evaluation of germ plasm and to investigate the mechanisms and genetic control of resistance in order to aid in the regulatory aspects of plum pox disease spread and to provide stone fruit and ornamental Prunus breeders with unique sources of resistance for breeding programs.

\section{ACKNOWLEDGMENTS}

We acknowledge the efforts of William Sackett (PSU) for aphid rearing and transport; and Sandra Sorensen, Diana Sherman, Katherine Shank, Micki Kuhlmann, and Phaedra O'Connell (USDA) for excellent assistance in ELISA and PCR analysis.

\section{LITERATURE CITED}

1. Atanasoff, D. 1932. Plum pox. A new virus disease. Ann. Univ. Sofia, Fac. Agric. Sil- vic. 11:49-69.

2. Bassett, C., Callahan, A., and Dunn, L. 1998. Characterization of a type II chlorophyll a/bbinding protein gene $(\mathrm{Lhcb} 2 * \mathrm{Pp} 1)$ in peach (Prunus persicae [L.] "Batsch: 1. Isolation, identification and abundance in developing leaves. J. Am. Soc. Hortic. Sci. 123:486-492.

3. Baumgartnerova, H. 1997. Walnut - a new host of sharka virus? Proc. Middle European meeting '96 Plum pox. Budapest, Oct 2-4, 1996:104-106.

4. Brunt, A. A., Crabtree, K., Dallwitz, M. J., Gibbs, A. J., Watson, L., and Zurcher, E. J., eds. 1996 onward. Plant Viruses Online: Descriptions and Lists from the VIDE Database. Version: 20th August 1996. Published online.

5. Candresse, T., Macquaire, G., Lanneau, M., Bousalem, M., Wetzel, T., Quiot-Douine, L., Quiot, J. B., and Dunez, J. 1994. Detection of plum pox potyvirus and analysis of molecular variability using immunocapture-PCR. EPPO Bull. 24:585-594

6. Christoff, A. 1934. Mosaikkrankheit oder Viruschlorose, bei Äpfeln. Eine neue Viruskrankheit. Phytopathol. Z. 7:521-536.

7. Clark, M. F., and Adams, A. N. 1977. Characteristics of the microplate method of enzyme linked immunosorbent assay for the detection of plant viruses. J. Gen. Virol. 34:475-483.

8. Damsteegt, V. D., Stone, A. L., Schneider, W., Luster, D. G., and Gildow, F. E. 2004. Potential Prunus host range of PPV-PENN isolates by aphid transmission. Acta Hortic. 657:201205.

9. Dunez, J. 1988. Plum pox disease of stone fruits in Egypt. Report of a mission to Egypt. TCP/EGY/6759. 8 pages.

10. Gildow, F., Damsteegt, V., Stone, A., Schneider, W., Luster, D., and Levy, L. 2004. Plum pox in North America: Identification of aphid vectors and a potential role for fruit in virus spread. Phytopathology 94:868-874.

11. Glasa, M., Marie-Jeanne, V., Labonne, G., Šubr, Z., Kudela, O., and Quiot, J. B. 2002. Natural population of recombinant Plum pox virus is stable and competitive under field conditions. Eur. J. Plant Pathol. 108:843-853.

12. Glasa, M., Palkovics, L., Kominek, P., Labonne, G., Pittnerová, S., Kudela, O., Candresse, T., and Šubr, Z. 2004. Geographically and temporally distant natural recombinant isolates of Plum pox virus are genetically very similar and form a unique PPV subgroup. J. Gen. Virol. 85:2671-2681.

13. Grüntzig, M., Fuchs, E., and Kegler, H. 1986. Studies on the identification of plum pox virus in plum trees. Archiv. Phytopathol. Pflanzenschutz 22:441-449.

14. Hamdorf, G. 1975. Further studies about the host range of Sharka (plum pox) virus. Acta Hortic. 44:155-162.

15. Herrera, G. 1994. Detecciön de la enfermedad de Sharka (Plum pox virus) en una vieja colecciön de carozos en la subestaciön Los Tilos (INIA), Chile. Agric. Técnica (Chile) 54:187191.

16. Hily, J. M., Scorza, R., Webb, K., and Ravelonandro, M. 2005. Accumulation of the long class of siRNA is associated with resistance to Plum pox virus in a transgenic woody perennial tree. Mol. Plant-Microbe Interact. 18:794-799.

17. James, D., Varga, A., Thompson, D., and Hayes, S. 2003. Detection of a new and unusual isolate of plum pox potyvirus in plum (Prunus domestica). Plant Dis. 87:1119-1124.

18. Jordović, M. 1965. The rate of spread of sharka (plum pox) virus in some plum varieties in nature. Zašt. Bilja 16:353-356.
19. Labonne, G., Boeglin, M., and Monsion, B. 2004. Evaluation of three ornamental Prunus as reservoirs of PPV. Acta Hortic. 657:255259.

20. Labonne, G., Yvon, M., Quiot, J. B., Avinert, L., and Llacer, G. 1995. Aphids as potential vectors of Plum pox virus: Comparison of methods of testing and epidemiological consequences. Acta Hortic. 309:129-134.

21. Levy, L., Damsteegt, V., and Welliver, R. 2000. First report of plum pox virus (Sharka Disease) in Prunus persicae in the United States. Plant Dis. 84:202.

22. Martínez-Gómez, P., Rubio, M., and Dicentra, F. 2003. Evaluation of resistance to Plum pox virus in North American and European apricot cultivars. HortScience 38:568-569.

23. Melching, J. S., Bromfield, K. R., and Kingsolver, C. H. 1983. The plant pathogen containment facility at Frederick, Maryland. Plant Dis. 67:717-722.

24. Navratil, M., Safarova, D., Karesova, R., and Petrzik, K. 2005. First incidence of Plum pox virus on apricot trees in China. Plant Dis. 89:338.

25. Németh, M. 1963. Field and greenhouse experiments with plum pox virus. Phytopathol. Mediterr. 2:162-166.

26. Németh, M. 1986. Virus, mycoplasma, and rickettsia diseases of fruit trees. Martinus Nijhoff Pub., Dordrecht, Netherlands.

27. Németh, M. 1994. History and importance of plum pox in stone-fruit production. EPPO Bull. 24:525-536.

28. Polak, J. 1997. On the epidemiology of Plum pox virus in the Czech Republic. Ochrana Rostlin 33:81-88.

29. Polak, J. 2001. European spindle tree and common privet are new natural hosts of plum pox virus. Acta Hortic. 550:125-128.

30. Polak, J. 2001. Occurrence of plum pox virus in plums, myrobalans, blackthorns, apricots, and peaches in South Moravia along the Austrian border. Plant Prot. Sci. 35:93-95.

31. Polak, J. 2004. Variability in susceptibility to Plum pox virus in natural woody hosts, Myrobalan and Blackthorn. Acta Hortic. 657:261264.

32. Roy, A. S., and Smith, I. M. 1994. Plum pox situation in Europe. EPPO Bull. 24:515-523.

33. Schneider, W. L., Sherman, D. J., Stone, A. L Damsteegt, V. D., and Frederick, R. D. 2004. Specific detection and quantification of Plum pox virus by real-time fluorescent reverse transcription-PCR. J. Virol. Methods 120:97-105.

34. Šutić, D. 1972. Sarka (Plum pox) virus disease. Project No. E30-CR-19, PL 480, Fin. Tech. Rep. Pages 348-354 in: Handbook of Plant Virus Diseases. D. D. Šutić, R. E. Ford and M. T. Tosic, eds. CRC Press 1999.

35. Šutić, D., Jordović, M., Ranković, M., and Festić, H. 1971. Comparative studies of some sharka virus isolates. Ann. Phytopathol. No. hors serie:185-194.

36. Thompson, D., McCann, M., MacLeod, M., Lye, D., Green, M., and James, D. 2001. First report of plum pox potyvirus in Canada. Plant Dis. 85:97.

37. Van Oosten, H. J. 1975. Susceptibility of some woody plant species, mainly Prunus spp., to sharka (plum pox) virus. Neth. J. Plant Pathol. 81:199-203.

38. Wallis, C. M., Fleischer, S. J., Luster, D., and Gildow, F. E. 2005. Aphid (Hemiptera: Aphididae) species composition and potential aphid vectors of Plum pox virus in Pennsylvania peach orchards. J. Econ. Entomol. 98:1441-1450. 